\title{
US electric deregulation: still critically important
}

\author{
By Edward L Flippen
}

$\mathrm{N}$ ot too long ago, the electric deregulation train appeared to have gathered steam across most of the country and seemed unstoppable. Recently, however, electric deregulation appears to have lost pace, and in some quarters what little accomplishment there has been is being rolled back or stalled. Certainly, not every state jumped on the train. States such as Idaho, Wyoming, Kentucky, Tennessee, Utah, and West Virginia have had little incentive to deregulate. The average price their citizens pay for electricity is in the range of $\$ 0.05 / \mathrm{kWh}$ or less compared to prices 80-100 percent higher in California, Massachusetts, Rhode Island, Maine, Vermont, Connecticut, New Jersey, New York, and New Hampshire. But even in states where there have been economic and policy incentives to deregulate, much has happened in the last few years to stifle deregulation.

The California energy crisis left legislators and regulators in the states that have not deregulated with grave concerns about whether deregulation even works, much less whether it will produce consumer benefits. Rates for customers of San Diego Gas and Electric increased 100 to 200 percent in 2000, and Pacific Gas \& Electric and Southern California Edison had to pay for wholesale purchases of electricity at prices that were up to five times greater than what they were able to recover from their retail customers. All in all, a California deregulation plan that took five years to develop took only months to collapse. And, now, the state of California (through its Department of Water Resources) owes billions for long-term obligations it incurred to purchase electricity for its residents when California utilities were unable to meet their obligations.

As if the combination of low cost states trying to hold onto regulation and the California fiasco were not enough, along comes the collapse of Enron. Enron was the 'poster child' of electric deregulation. It promoted greater competition in electric power and battled state regulators that opposed deregulation. However, the company overstated profits with allegedly fraudulent accounting and, certainly, dubious accounting such as booking the entire value of energy future trades as revenue. (Trading firms typically only book the spread between purchases and sales, not the whole trade). The result was artificially inflated values that, together with loose accounting practices, ultimately caused its demise.
Mix the ingredients of low cost states wanting to hold onto regulation in their states, the California debacle, and the collapse of Enron, and it would be easy to conclude that electric deregulation is doomed. Yet, just the opposite should be the case. Not a single customer has been without electric service because of Enron. And the lessons from the California crisis tell us how better to model deregulation. For sure, states must make certain there is a balance in the supply and demand for electricity at the time of deregulation (California had no net increase in generating facilities over a 10 year period in which demand increased by approximately 25 per cent). Equally important, states must allow retail electric distribution utilities to enter into long-term supply arrangements with deregulated generation plants. (California encouraged its incumbent electric utilities to divest their generation, capped their retail rates, and prohibited them from entering into long-term supply contracts). The net result was that the incumbents were exposed to spot market volatility and squeezed to the point of insolvency.

Regardless of California and Enron, we know from the Australian and UK electric deregulation experience, as well as the US telecommunications experience, that deregulation drives prices down. We also know from the US telecommunications experience that deregulation produces quantum leaps in technology advances. And we know from our experience with airline, trucking, and railroad deregulation that competition reduces cost and increases efficiencies.

Deregulation of anything faces 'bumps in the road'. But when the bumps are gone, prices are lower and services are better, relatively speaking. The only thing we do not know is whether politicians can take the heat caused by the bumps. If they can, electric deregulation will produce lower prices, better service, and add value to the global competitive position of US firms. If they can't, the continued confusion and uncertainty in the electric power industry will be a drag on the US economy. Then everyone will lose.

Edward L Flippen

Mr. Flippen is a partner with McGuire Woods LLP and a visiting professor

of law at George Mason University School of Law: 